DOI: https://doi.org/10.32839/2304-5809/2021-4-92-55

УДК 34.096

Ільченко О.В., Ільченко Б.О.

Сумський державний університет

\title{
ПРАВОВІ АСПЕКТИ ЩОДО РЕАЛІЗАЦІЇ КОНЦЕПЦІЇ НАЦІОНАЛЬНОЇ БЕЗПЕКИ УКРАЇНИ
}

\begin{abstract}
Анотація. Національна безпека є одним з найголовніших умов існування та функціонування держави та суспільства. Стаття присвячена концепції національної безпеки України, та її ролі у визначенні напрямку розвитку держави, розглянуто важливість національної безпеки на основі аналізу походження суспільства. Визначено роль концепщії національної безпеки України яка е основоположним та системоутворюючим документом, що відображае генеральний план щодо забезпечення безпеки нації, без створення якого вироблення дієвих засобів гарантування національної безпеки країни практично неможливе. У статті на основі теоретичних положень досліджено як внутрішньодержавні так і зовнішні чинники, що негативно впливають на стан національної безпеки України, запропоновано шляхи їх усунення, розкрито ключові питання щодо необхідності створення нової концепції національної безпеки та загального реформування сектору національної безпеки.
\end{abstract}

Ключові слова: національна безпека, концепція, розвиток, реформування системи безпеки, безпека нації.

Ilchenko Oleksandr, Ilchenko Bohdan Sumy State University

\section{LEGAL ASPECTS REGARDING THE IMPLEMENTATION OF THE CONCEPT OF NATIONAL SECURITY OF UKRAINE}

Summary. National security is one of the most important conditions for the existence and functioning of the state and society. Scholars also call national security the security of the nation and understand the protection of vital interests of the individual, society and the state in various spheres of life from internal and external threats, which ensures the sustainable development of the country. In this case, security means the ability to maintain the object or system of its qualitative certainty and the ability to perform its functions under the influence of negative factors. The emergence of modern processes of globalization and interaction of states with each other has led to the fact that each country needs to improve and find new approaches to national security. Ukraine is no exception, but to create a strong mechanism it is necessary to take into account many factors that cover all areas of state activity. One of the most important reasons for the lack of a vision of a holistic concept of Ukraine's national security in domestic theoretical and political thought is a certain underestimation of the role and importance of civil society in ensuring national security. After all, it is able to ensure the unity of man, society, nation, state and organize proper civilian control over national security, to ensure stable and safe development of society in all spheres of its life. The formation of a holistic comprehensive concept of national security of Ukraine would contribute to the involvement of all citizens, public and political associations in open public discussion of national security issues and the development of a clear concept of national interests of Ukraine software. The article is devoted to the concept of national security of Ukraine, and its role in determining the direction of development of the state, the importance of national security is considered on the basis of the analysis of the origin of society. The role of the concept of national security of Ukraine is defined, which is a fundamental and system-forming document that reflects the master plan for ensuring the security of the nation, without which the development of effective means of guaranteeing national security is virtually impossible. Based on theoretical provisions, the article examines both domestic and external factors that negatively affect the state of national security of Ukraine, suggests ways to eliminate them, reveals key issues regarding the need to create a new concept of national security and general reform of the national security sector.

Keywords: national security, concept, development, security system reform, security of nation.

$\Pi^{2}$ остановка проблеми. Забезпечення національної безпеки держави є однією з головних питань для сучасної України. Військові дії на сході держави вказали на ряд суттєвих проблем у сорері забезпечення національної безпеки як всередині держави так і в зовнішній політиці. Впровадження дієвих засобів, що мають забезпечити високий рівень нащіональної безпеки в державі неможливе без створення єдиної концепції яка $€$ фундаментальним та системоутворюючим документом, що відображає генеральний план забезпечення безпеки нащії. На основі теоретичних положень нами розглядаються як внутрішні, так і зовнішні фрактори, що негативно впливають на стан національної безпеки України, пропонуються шляхи їх усунення, розкриваються ключові питання щодо необхідності створення нової концепції національної безпеки та загальної реформи національної сектор безпеки.

Аналіз останніх досліджень та публікацій. Питанню дослідження концепції національної безпеки у різних аспектах та актуальність їі впровадження станом на сьогодні приділяли достатньо часу в наукових публікаціях та статтях такі українські вчені, як Смолянюк В.Ф., Деменко О.Ф., Прибутько П.С., Ліпкан В. А., Антонов B.О., Зіневич О.В., Гвоздь В.I. та інші.

Раніше не вирішеними проблемами с: Станом на сьогодні, основні проблеми реалізації національної безпеки виникають саме через недосконалу нормативну базу. Основоположним документом у ієрархічній системі нормативних документів вважається концепція, яка відображає генеральний план щодо забезпечення безпеки на- 
ції та є підгрунтям для прийняття стратегій, доктрин та інших нормативно-правових документів. Наразі в Україні відсутня стратегія національної безпеки, що негативно впливає на вирішення багатьох питань що стосуються безпеки нації.

Метою даної статті $є$ теоретико-правовий аналіз загроз національної безпеки та вироблення шляхів їх вирішення завдяки створенню нової концепції національної безпеки.

Викладення основного матеріалу. Ще 3 давніх часів безпека була ключовою метою, задля чого люди об'єднувалися в общини, та поділяли обов'язки між собою. Чим більшого розвитку набувало суспільство, тим більше загострювалося питання забезпечення безпеки цивілізації, а потім вже й держави. Безпека охоплює усі сфери життедіяльності та гарантуе максимальний суспільний розвиток. Насправді ж, важко виокремити розвиток від безпеки. Обидва явища доповнюють одне-одного.

Фактично, більше можливостей забезпечення безпеки мають країни, які знаходяться на вищій стадії розвитку. На відміну від розвитку, сутність якого полягає в розширені та вдосконаленні всіх сфрер суспільної діяльності, безпека ж, у свою чергу, вимагає стабільності. На жаль, розвиток системи національної безпеки України залишає бажати кращого, у нашій державі налічуеться велика кількість наукових інститутів, але не один з них цілком ретельно не намагався вивчити та розібрати цю важливу сферу державної політики [1].

Як зазначає Ліпкан В.А., Україна - держава 3 яскравою історією, але незважаючи на власний досвід, великі потрясіння і втрати населення, наша держава й до сьогодні не може створити ефрективного механізму захисту країни від небезпеки, що вже призвело до фратальних наслідків всередині держави [2].

Взагалі, національну безпеку вчені також називають безпекою нації й під цим поняттям розуміють захищеність життево важливих інтересів особи, суспільства і держави в різних сдерах життедіяльності від внутрішніх і зовнішніх загроз, що забезпечуе сталий поступальний розвиток країни. При цьому, під захищеністю розуміеться здатність збереження об'єктом або системою своєї якісної визначеності і можливості виконання своїх фрунцій в умовах впливу негативних фракторів. Поява сучасних процесів глобалізації та взаємодії держав одна з одною призвела до того, шо кожній країні треба вдосконалювати та знаходити нові підходи національної безпеки. Україна не є винятком, але для створення сильного механізму треба врахувати безліч фракторів, які охоплюють всі напрямки діяльності держави [2].

Для забезпечення нащіональної безпеки, держава обов'язково повинна мати нормативно-правове забезпечення для џього. Станом на сьогодні, основні проблеми реалізації безпеки нації виникають саме через недосконалу нормативну базу. Ми живемо в сучасному світі й всі сфери нашої діяльності трактуються завдяки чинному законодавству. Бо лише закони надають сприятливі умови для створення відповідного громадянського суспільства, шо є невід'ємною частиною держави. Правове регулювання повинно випливати із основоположних норм, понять, механізмів а також об'єднань різних методів комплексного міждисциплінарного підходу. Це необхідно через безпосередні потреби українського народу у розвитку та захисті, наявності певних компетентних державних органів, які б приймали певні рішення у зовнішніх та внутрішніх справах.

На думку Антонова В.О., документи, які створюють основи для національної безпеки повинні мати власну ієрархію. Основоположним документом у цій іерархічній системі вважається концепція, яка відображає генеральний план щодо забезпечення безпеки нащії. Цей документ включає в себе сукупність ідей та уявлень щодо розвитку держави, спираючись на природу та походження держави, тобто іï історичне минуле та досвід поколінь. Слід сказати, що концепція надає певне бачення щодо вирішення різного роду проблем, сукупність понять і зв'язків між ними, визначає основні напрями розвитку і характеристики будьякого явища. На відміну від стратегії, концепція несе в собі основні положення, які мають стати підгрунтям для успішних стратегій і доктрин. Саме Концепщія нащіональної безпеки виконуе інструментальну фрункщію - за їі допомогою формується ієрархічна система нормативно-правових актів, що регулює суспільні відносини в сфері національної безпеки [3]. Ми вважаємо, що доктрини, стратегії та інші нормативно-правові акти, які впливають на забезпечення національної безпеки України, повинні базуватися перш за все на Конституції та Концепції національної безпеки. Інші другорядні документи лише конкретизують та деталізують положення Концепцї, впроваджуючи дієву систему розвитку певної сорери життедіяльності.

Прийняття Концепції національної безпеки України, Закону України «Про основи національної безпеки України» від 19 червня 2003 року, який скасував чинність Концепції, а також Закон України «Про нащіональну безпеку України» від 21 червня 2018 року стало поки єдиним кроком 3 формування законодавчого підгрунтя фрункціонування системи національної безпеки.

Iз тих положень, що були зазначені вище, можна зрозуміти, що дійсно помітного розвитку будь-яка держава може здобути лише за налагодженої системи національної безпеки. У свою чергу, нормативна база безпеки нації забезпечується концепцією, яка надає повне бачення, яким чином державі треба рухатися в майбутньому та який стратегічний шлях обирати. На жаль, станом на сьогодні, в Україні відсутня концепція національної безпеки. Усвідомлюючи ці фракти, стає цікаво: яким чином наша держава зможе досягти бажаного розвитку, не маючи базису для забезпечення власної безпеки, яка за своєю ж природою покликана забезпечувати стабільний розвиток?

Нещодавно Президент України Володимир Зеленський увів у дію рішення Ради національної безпеки і оборони від 25 березня 2021 року «Про Стратегію воєнної безпеки України». Відповідний указ № 121/2021 Глава держави підписав 25 березня [4]. Треба розуміти, що Україна має стратегії розвитку національної безпеки, але вони спираються лише на Конституцію, що є вкрай некоректно. Тому, ми вважаємо що певного роду стратегії, які не мають власного ядра такого як концепція, приречені на провал. Чудовим при- 
кладом може слугувати етапи побудови власного будинку. Уявимо, що будинок - це є нащіональна безпека України, та як наслідок подальший ії розвиток. Цегли будинку - це стратегії та доктрини, а концепція - це фрундамент будинку, тобто основа. Тому, як би люди не намагалися скласти цеглини в купу та побудувати будівлю, ніхто не зробить цього, допоки не з'явиться фрундамент. Таким чином, у настільки важкий для країни час, подальший розвиток неможливий без впровадження Концепції національної безпеки України. Ми вважаємо, що саме відсутність фунддаментального документу та слабкої державної політики керівництва призводить до тих негативних змін, які зараз відбуваються всередині країни.

Ще 21 грудня 2000 року Верховна Рада України винесла постанову Про Концепцію національної безпеки. Ми вважаємо, що цей документ дійсно відображував основні ідеї та цінності держави. Пріоритетними національними інтересами України відповідно до Концепції на той час були:

- досягнення нащіональної злагоди, політичної і соціальної стабільності, гарантування прав української нації та національних меншин України;

- забезпечення державного суверенітету, територіальної цілісності та недоторканності кордонів;

- збереження та підвищення науково-технологічного потенціалу;

- зміцнення генофонду Українського народу, його фрізичного і морального здоров'я та інтелектуального потенціалу;

- налагодження рівноправних та взаємовигідних відносин з усіма державами, інтегрування в європейську та світову спільноту [5].

Можна об’єктивно стверджувати, що плани, які містилися у џьому нормативно-правовому акті не були втілені в реальність, окрім створення громадянського суспільства, яке змогло б відстояти свої права. Дійсно, нещодавні події в сусідніх країнах, таких як Росія та Білорусь, дали чітке розуміння того, що в порівнянні 3 іншими націями, українська повністю здатна отримати бажаного та стояти до останнього заради цього. Усвідомлення цього фракту може слугувати поштовхом подальшого розвитку держави. Становище в Україні різко змінюеться з кожним днем протягом вже семи років і нам здається, що прийшов час чітко окреслити теоретико-правові засади подальшого розвитку держави на основі нової Концепцї нащіональної безпеки України.

На думку О. Зіневича, оновлення та редрормування системи національної безпеки мало було відбутися ще у 2014 році задля надання чітких позищій щодо державних інтересів та дій спрямованих на їх реалізацію. На жаль, треба констатувати той фракт, що система забезпечення національної безпеки України у свій час не змогла протистояти агресії російських військ, що спричинило великі втрати. Сектор безпеки та оборони є основним складовим елементом системи забезпечення безпеки нації, але він цілком не сформований до цьог часу і не готовий діяти як єдина фрункціональна структура. Більша частина техніки та озброєння фрізично застаріла. Військові та поліцейські фрормування ще не готові були брати участь у воєнних конфоліктах через відсутність матеріально-технічного, кадрового та розвідувального забезпечення [6].
Взагалі, оновлення будь-якого явища являє собою процес, який залежить від багатьох чинників, тому редрормування, як саме поняття не може бути одноразовим. Таким чином, на стан безпеки нації України впливають, як і внутрішні чинники, так і зовнішні. Саме на ці фрактори повинно покладатися керівництво під час створення нової Концепції державної безпеки. Зміна пріоритетів відбувається внаслідок геополітичної, економічної, внутрішньої ситуацій та інших глобалізаційних процесів, що дають нові шляхи редормування, відповідно до нових пріоритетів та задач. Багато вчених вважають події 2014 року великою помилкою державного керівництва, яка стала причиною фрізичної неспроможності України реалізувати свою головну мету - інтеграцію в Свропейський Союз.

Свроінтеграція неможлива, якщо в державі відбуваються воєнні дії, через це Україна зіштовхнулась 3 великою кількістю проблем, які потребують негайного вирішення. Ми розуміємо, що бойові дії на Донбасі представляють собою не лише агресію з боку Росї, а ще й комплекс невдалих рішень та дій з боку української влади. Ця ситуація є історично вагомою для України, тому вона має слугувати серйозним досвідом задля покращення національної безпеки. Як ми зазначали вище, стратегії не є максимально дієвими, якщо вони не мають власного підгрунтя від якого можуть відштовхуватись. На наш погляд, наша держава повинна усвідомлювати та аналізувати всі загрози, які стоять перед нею задля того, щоб безпосередньо почати діяти. Крім того, треба розуміти, яким чином треба вдосконалювати роботу системи національної безпеки, щоб вирішення одніеї проблеми не спричинило виникнення кількох інших. Лише після ретельного аналізу та вивчення становища держави, можна говорити про реформування системи.

Україна, на сьогоднішній момент, стикається 3 рядом загроз у політичній, економічній, соціально-демографічній, воєнній, релігійній та інформаційній сфрерах, вирішення яких потребує часу та колосальної уваги з боку держави. Як наслідок, можна стверджувати той фракт, що рефрормування системи національної безпеки потрібно здійснювати негайно.

Перше на що ж все-таки треба звернути увагу, то це на відсутність концепції, яка могла б позитивно вплинути на перебіг подій. Треба чітко визначитись із вектором розвитку нашої держави, врахувати досвід минулих поколінь та надати нових ідей та іншого бачення на все, що відбувається зараз в Україні. Концепція призвела б до оновлення стратегій та доктрин, які можуть стати більш дієвими ніж вони е зараз. Якщо ж відходити від теоретичної частини, то звичайно треба надати увагу редормуванню СНБ у сфрері зовнішньої політики, у військовій сфрері, а також у сфрері оборони державного кордону.

Якщо говорити про зміни в зовнішньополітичній сфері то варто звернути увагу на слова О. Зіневич, яка відмітила, що важливим є приєднання до міжнародних інституцій, які засновані на гуманних цінностях, участь у їх діяльності $є$ істотною частиною Стратегії, яка визначає як пріоритет європейську та євроатлантичну інтеграцію України. Крім цього, треба створити едективну 
систему нейтралізації зовнішніх загроз та створення зручного середовища для України на міжнародній арені. Але найважливішим у цьому питанні є захист від впливу, з боку іноземних компаній та держав у цілому, на внутрішні та зовнішні справи України [6].

Як зазначає Гвоздь В.В., органи розвідки відіграють колосальну роль у забезпечені національної безпеки також. Важко переоцінити роль подібного інституту, достатньо звернутися до основного закону, який регламентує діяльність розвідки - Закону «Про розвідувальні органи України». У ньому зазначається, що «на розвідувальні органи України покладається здійснення спеціальних заходів, спрямованих на підтримку національних інтересів і державної політики України в економічній, політичній, воєнній, військово-технічній, екологічній та інформаційній сдерах, зміџнення обороноздатності, економічного і науково-технічного розвитку, захисту та охорони державного кордону». Звідси можна зрозуміти, що основними завданнями, які покладені законодавством на розвідувальні органи, є: збір та аналіз інформації, здійснення спеціальних заходів пов'язаних 3 підтримкою національних інтересів, забезпечення безпечного фрункціонування установ України за кордоном, безпеки співробітників цих установ та членів їх сімей у країні перебування, беруть участь у боротьбі 3 тероризмом, протидіють зовнішнім загрозам національній безпеці України [7]. Розвідка може допомогти в боротьбі з тероризмом, який станом на сьогодні являе собою серйозну загрозу для України. Тому система національної безпеки має застосовувати всі можливі засоби задля уникнення негативних наслідків можливих загроз.

Висновок. Система нащіональної безпеки переживає не найкращі часи, але при цьому аналізуючи можливості та безпосередній потенціал нашої держави, хочеться вірити, що все-ж-таки настане час й Україна почне свій масштабний шлях розвитку на який ми всі так довго чекаємо. Починати треба 3 дрібниць і закладати основи подальшого розвитку, тому без нової концепції розвитку безпеки нащії шлях розвитку українського народу буде набагато складнішим. Ми вже визначилися із тим що вирішальними чинниками які впливають на СНБ є курс зовнішньої політики та внутрішньополітична обстановка в країні. Усвідомлюючи сутність всіх проблем та загроз через які доводиться проходити нашій державі, з'являється негайна потреба у редрормуванні системи національної безпеки, яка б змогла надійно виконувати свої функції та забезпечувати природний розвиток суспільству та державі. Лише швидка реакція з боку держави може сприяти ефективній боротьбі із потенційними загрозами які загрожують країні. Лише коли кожен структурний орган буде виконувати свої фрункції на максимальному рівні, тільки тоді можна очікувати певних результатів у всіх сфрерах людської діяльності.

\section{Список літератури:}

1. Смолянюк В.Ф., Деменко О.Ф., Прибутько П.С. Основи національної безпеки України : навч. посіб. Київ : Паливода А.В., 2017. С. 6-38.

2. Ліпкан В.А. Національна безпека України : навч. посіб. Київ : КНТ, 2009. С. 193-198.

3. Антонов В.О. Конституційно-правові засади національної безпеки України : монографрія; наук. ред. Ю.С. Шемшученко. Київ : Талком, 2017. С. 219-480.

4. Указ Президента України «Про рішення Ради національної безпеки і оборони України від 25 березня 2021 року «Про Стратегію воєнної безпеки України» № 121/2021 від 25 березня 2021 року. URL: https://zakon.rada.gov.ua/laws/show/121/2021\#Text

5. Про Концепцію (основи державної політики) національної безпеки України : Постанова Верховної Ради України від 21.12.2000 № 9. URL: https://zakon.rada.gov.ua/laws/show/3/97-\%D0\%B2\%D1\%80\#Text

6. Зіневич О. Пріоритети та реформування системи забезпечення національної безпеки України в сучасних умовах. Національний університет «Киево-Могилянська академія». 14.02.2020.

7. Гвоздь В.І. Історичні, правові і політичні аспекти розвідувальної діяльності держави. Київ, 2018. С. $389-519$.

\section{References:}

1. Smolyanyuk V.F., Demenko O.F., Prybutko P.S. (2017) Osnovy nacionalnoyi bezpeky Ukrayiny [Basics of national security of Ukraine]. Kyiv: Palyvoda A.V.

2. Lipkan V.A. (2009) Nacionalna bezpeka Ukrayiny [National security of Ukraine]. Kyiv: KNT.

3. Antonov V.O. (2017) Konstytucijno-pravovi zasady nacionalnoyi bezpeky Ukrayiny [Constitutional and legal principles of national security of Ukraine]. Kyiv: Talkom.

4. Ukaz Prezydenta Ukrayiny «Pro rishennya Rady nacionalnoyi bezpeky i oborony Ukrayiny vid 25 bereznya $2021 \mathrm{roku}$ "Pro Strategiyu voyennoyi bezpeky Ukrayiny" № 121/2021 vid 25 march 2021 roku. Available at: https://zakon.rada.gov.ua/laws/show/121/2021\#Text

5. Pro Koncepciyu (osnovy derzhavnoyi polityky) nacionalnoyi bezpeky Ukrayiny: Postanova Verxovnoyi Rady Ukrayiny vid 21.12.2000 № 9. Available at: https://zakon.rada.gov.ua/laws/show/3/97-\%D0\%B2\%D1\%80\#Text

6. Zinevych O. (2020) Priorytety ta reformuvannya systemy zabezpechennya nacionalnoyi bezpeky Ukrayiny v suchasnyx umovax [Priorities and reforming the system of national security of Ukraine in modern conditions]. Kyiv: Nacionalnyj universytet «Kyevo-Mogylyanska akademiya».

7. Gvozd V.I. (2018) Istorychni, pravovi i politychni aspekty rozviduvalnoyi diyalnosti derzhavy [Historical, legal and political aspects of state intelligence]. Kyiv. 